\title{
KOMPARASI MODEL PERAMALAN DEBIT SUNGAI MENGGUNAKAN ANN- SOM ANN PADA SUB DAS TAPUNG KIRI
}

\author{
Mukhelnalis Sutazril $^{1)}$, Imam Suprayogi ${ }^{2)}$, Ferry Fatnanta ${ }^{3)}$ \\ ${ }^{1)}$ Mahasiswa Magister Teknik Sipil, Fakultas Teknik, Universitas Riau. \\ ${ }^{2)}$ Dosen Magister Teknik Sipil, Fakultas Teknik, Universitas Riau. \\ ${ }^{3}$ Dosen Magister Teknik Sipil, Fakultas Teknik, Universitas Riau.
}

\section{N F O ARTIKEL}

Histori artikel:

Diajukan 15 Desember 2020

Diterima dalam bentuk revisi

Diterima

Tersedia Online

\begin{abstract}
ABSTRA K
Sub daerah aliran sungai Tapung Kiri merupakan bagian dari daerah aliran sungai Siak yang dikategorikan sebagai daerah aliran sungai kritis dan kawasan rawan bencana banjir. Potensi terjadinya banjir disebabkan oleh tingginya curah hujan diwilayah tengah, hulu dan di sepanjang daerah aliran sungai yang telah mengalami perubahan tata guna lahan. Pada penelitian ini, dilakukan model peramalan debit dengan menggunakan metode artificial neural network, diharapkan untuk menyediakan data peramalan debit yang lebih terpercaya untuk masa yang akan datang sehingga dapat menjadi acuan bagi sistem peringatan dini. Data yang digunakan adalah data ketinggian muka air sungai Tapung Kiri dari peralatan automatic water level recorder Pantai Cermin deng an panjang data selama 15 tahun, dimulai pada tahun 2005 sampai dengan tahun 2019. Penelitian ini diharapkan bisa memberikan gambaran tentang keunggulan dari artificial neural network untuk digunakan sebagai sistem peringatan dini terhadap banjir. Hasil penelitian menunjukkan bahwa menggunakan metode articial neural network menghasilkan nilai koefesien korelasi pada tahap pelatihan sebesar 0,98 , pada tahap pengujian sebesar 0,85 dan pada tahap validasi sebesar 0,89 . Jumlah iterasi yang dibutuhkan pada metode artificial neuralnetwork adalah sebanyak 7515 epoch.
\end{abstract}

Kata kunci: artificial neuralnetwork, koefesien korelasi, peramalan debit

\section{E-M A I L}

mukhel.nalis@gmail.com drisuprayogi@yahoo.com

ferry.fatnanta@lecturer.unri.ac.id \begin{abstract}
ABSTRA CT
Tapung Kiri Sub river Basin is part of siak river basin which is categorized as a critical basin river and a flood prone area. The potential for flooding is caused by high rainfall in the middle, upstream and along basin river that have undergone land use changes. In this research, a discharge forecasting model was carried out using the artificial neural network method it is expected to provide more reliable forecasting for the future so that it can become reference for the early warning system.The data used is the data on the water level of the Tapung Kiri river from the automatic water level recorder for pantai cermin with a data length of 15 years, starting from 2005 to 2019 .This research is expected to provide an overview of the advantages of artificial neural network to be used as an early warning system against flooding.The result showed that using the artificial neural network method resulted in a correlation coeffecient value at the training stage of 0,98, at the testing stage of 0,85 and at the validation stage of 0,89.The number iterations required for the artificial neural network methodis 7515 epochs.
\end{abstract}

Kata kunci: artificial neural network, correlation coefficient, discharge forecasting

\section{PENDAHULUAN}

\subsection{Latar Belakang}

Banjir merupakan 1 dari 8 fenomena bencana alam besar di Indonesia pada tahun 2004-2016 yang menyebabkan hilangnya nyawa dalam skala besar, kerusakan infrastruktur, dan kerugian material, serta masalah kesehatan. Penilaian risiko probabilistik terhadap banjir yang dilakukan Indonesia melalui proyeksi spasial-eksplisit dari tahun 2000 hingga 2030 menunjukan peningkatan kawasan perkotaan yaitu 
$215 \%-357 \%$ dan paparan tersebut meningkatkan risiko banjir, rata-rata, $76 \%$ dan $120 \%$ untuk banjir sungai dan pesisir. Perubahan iklim juga memperbesar risiko banjir di pesisir sebesar 19-37\%, sementara dampak respon banjir di sungai menjadi tidak pasti (Muis et al.,2015). Peningkatan populasi dan pertumbuhan kota telah membuat konversi ruang terbuka serta perubahan iklim menjadi faktor utama risiko banjir (Ghozali et al.,2016).

Riau merupakan salah satu provinsi di Indonesia. Hingga saat ini, DAS ( Daerah Aliran Sungai) Siak masih dikategorikan sebagai DAS kritis yang merupakan kawasan rawan bencana banjir (Setyawati,2009). Potensi terjadinya banjir disebabkan oleh tingginya curah hujan diwilayah tengah, hulu dan di sepanjang DAS yang telah mengalami perubahan tata guna lahan. Banjir dan genangan sering terjadi didaerah yang dilalui Sungai Siak. Kota Pekanbaru menjadi salah satu daerah yang sering terkena dampak banjir dengan luas daerah rawan banjir mencapai 8.775 hektar (BWS Sumatera III, 2011).

Telah banyak model hidrologi yang sudah dikembangkan untuk prediksi debit ini baik dengan model fisik maupun dengan model softcomputing. Oleh karena membutuhkan tempat yang besar dan mahalnya biaya yang dibutuhkan dalam pembuatan model fisik ini, maka seiring berkembangnya teknik komputasi,penggunaan model softcomputing menjadi salah satu model yang patut untuk dicoba keandalannya.

Salah satu model softcomputing yang mendapat perhatian dalam pemodelan hidrologi akhir - akhir ini adalah model Jaringan Syaraf Tiruan (Artificial Neural Network). ANN adalah suatu teknik softcomputing untuk pengolahan informasi yang terinspirasi oleh sistem saraf secara biologis, seperti proses informasi pada otak manusia (kusumadewi, 2003).

Algoritma Backpropagation merupakan algoritma yang umum digunakan dalam metode SOMANN untuk menyelesaikan masalah yang berkaitan dengan peramalan. Namun kekurangan dari algoritma ini ialah penentuan bobot awal yang acak sehingga pelatihan jaringan menjadi kurang optimal. Farias (2015) telah melakukan penelitian mengenai penggunaan Self Organizing Maps (SOM) dan ANN dalam meramalkan sedimentasi memodelkan peristiw a runoff-erosion menjadi prediksi sedimentasi pada DAS Sume di daerah Paraiba, Brazil dengan nilai $\mathrm{R}=0,94$.
Model peramalan debit dengan ANN diharapkan dapat digunakan untuk menyediakan data peramalan debit yang lebih terpercaya untuk masa akan datang sehingga dapat menjadi acuan bagi Early Warning System untuk memberikan informasi terhadap potensi bencana banjir dan peramalan ketersediaan sumber daya air, sehingga peramalan yang dihasilkan dapat dijadikan sebagai alternatif pertimbangan pemerintah untuk mengambil keputusan dalam penyelenggaraan mitigasi bencana maupun perencanaan kegiatan konservasi sumber daya air. Dengan demikian, kegiatan di wilayah Sub DAS Tapung kiri diharapkan dapat berjalan dengan baik.

1.2 Tujuan berikut :

Tujuan dari penelitian ini adalah sebagai

1. Bagaimanakah unjuk kerja dari ANN untuk kebutuhan peramalan debit aliran sungai pada Sub DAS Tapung Kiri untuk panjang data debit 15 tahun

2. Bagaimana unjuk kerja dari metode gabungan SOM dan ANN untuk kebutuhan peramalan debit aliran sungai pada Sub DAS Tapung Kiri untuk panjang data debit 15 tahun

3. Bagaimana hasil perbandingan unjuk kerja antara penerapan model ANN dengan SOM - ANN untuk panjang data debit 15 tahun.

\section{MATERIAL DAN METODE}

2.1 Lokasi Penelitian

Lokasi penelitian adalah Sungai Tapung Kiri, dengan lokasi stasiun AWLR di Sungai Tapung Kiri, Desa Pantai Cermin, Kecamatan Tapung. Kabupeten Kampar, Provinsi Riau.

\subsection{Debit}

Menurut Asdak (1995) debit adalah laju aliran air yang melewati suatu penampang melintang sungai/aliran air per satuan waktu. Satuan debit yang lazim digunakan ialah m3/detik. Dalam hal ini, debit dapat juga dikatakan sebagai satuan besaran air yang keluar dari daerah aliran sungai. Fungsi dari

\subsection{Pengumpulan Data}

Data yang digunakan dalam penelitian ini adalah data dari AWLR yang telah dikonversi menjadi data debit dari tahun 2005 sampai tahun 2019 dengan persamaan liku kalibrasi $\mathrm{Q}=14,78 \times(\mathrm{H}+0,384)^{1,580}$, Sumber data diambil dari Balai Wilayah Sungai (BWS) Sumatera III Provinsi Riau, Jalan Cut Nyak Dien 01, Pekanbaru. 


\subsection{Analisis Data}

1. Clustering dengan Algoritma SOM

Struktur jaringan SOM yang digunakan pada penelitian ini ialah 4-n-n dengan $n$ adalah jumlah neuron dan cluster, yang berarti 4 input - $n$ neuron - $n$ output. Jumlah cluster ditentukan dengan jumlah neuron, yang berarti hasil pemrosesan input akan dicluster dan ditransfer ke layer output menjadi $\mathrm{n}$ cluster. Jumlah epoch yang diset ialah 1000 epoch (nilai default).

2. Membuat dan Melatih Jaringan

Agar algoritma SOM dan Backpropagation dapat terhubung dengan baik, maka diperlukan struktur yang serupa. Hal ini dikarenakan Software MATLAB bekerja dengan basis matriks sehingga diperlukan kesamaan ordo matriks antara kedua algoritma. Penentuan konstanta awal untuk parameter Momentum dan Learning dilakukan dengan cara trial and error. Algoritma pelatihan ini telah dibuktikan performanya oleh Mahyudin (2013) dengan hasil meningkatkan kestabilan jaringan pelatihan sehingga pelatihan menjadi konvergen lebih awal.

3. Pengujian Jaringan dan Peramalan

Setelah diperoleh korelasi yang terbaik dengan error yang minimal, dilakukan pengujian jaringan dengan data uji.

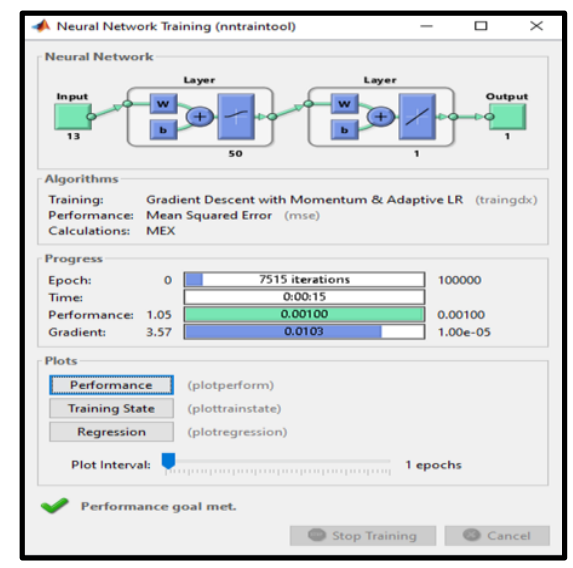

Gambar 1. Pemodelan Data Menggunakan ANN

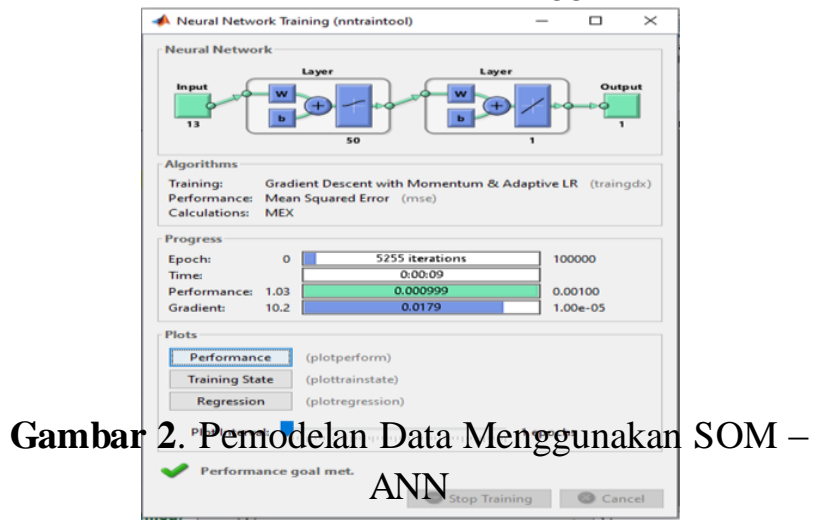

3.1 Pelatihan Jaringan Artificial Neural Network

\section{HASIL DAN PEMBAHASAN}

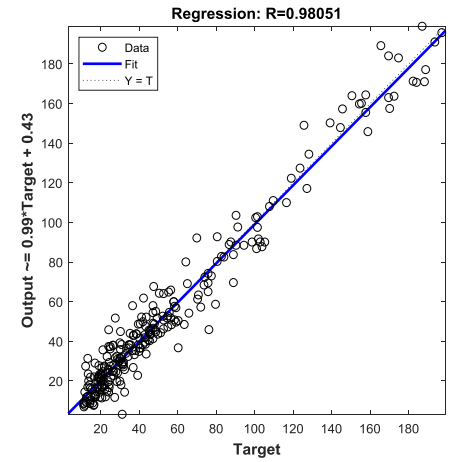

Gambar 3. Hubungan Debit Pemodelan dan Observasi Hasil Pelatihan Metode ANN

Gambar 3 memperlihatkan hubungan antara nilai output dan target dengan nilai $R=0,98051$. Grafik tersebut memperlihatkan hubungan antara debit pemodelan ANN dengan tinggi muka air sebagai target pelatihan. $R$ yang bernilai positif mengindikasikan peningkatan nilai target juga dibarengi dengan peningkatan nilai output secara umum.

\subsection{Pengujian Jaringan Artificial Neural Network}

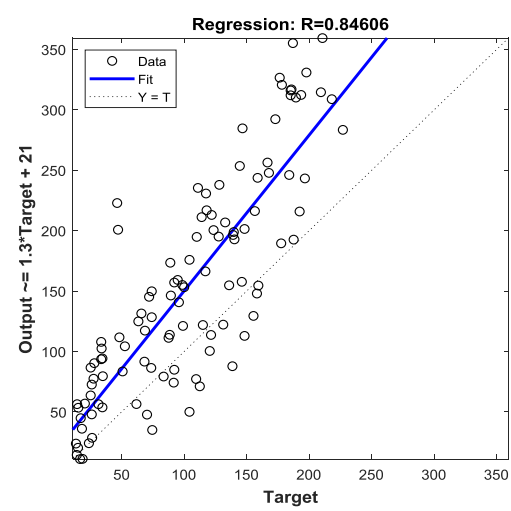

Gambar 4. Hubungan Debit Pemodelan dan Observasi Hasil Pengujian Metode ANN

Gambar 4 memperlihatkan nilai $\mathrm{R}$ uji hasil pengujian jaringan yang telah terbentuk pada proses pelatihan dengan nilai $\mathrm{R}=0,84606$ yang tergolong dalam kategori korelasi sangat kuat. Koefisien korelasi yang dihasilkan mengalami penurunan jika dibandingkan dengan koefisien yang diperoleh pada proses pelatihan.

\subsection{Validasi Jaringan Artificial Neural Network}




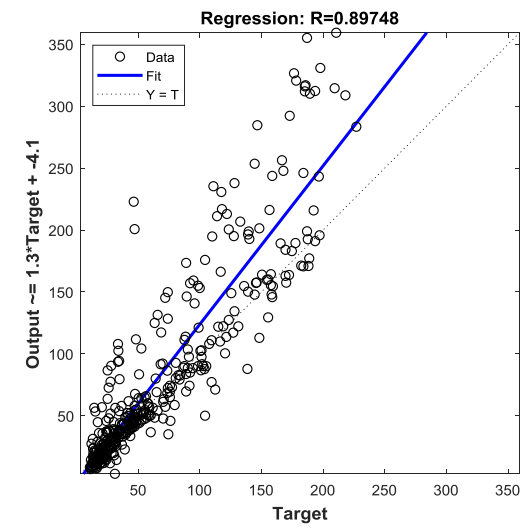

Gambar 5. Hubungan Debit Pemodelan dan Observasi Hasil Validasi Metode ANN

Gambar 5 memperlihatkan hubungan searah antara nilai output dan target dengan nilai $\mathrm{R}=0,89748$ yang masuk pada kategori korelasi sangat kuat. Nilai output dan target yang dihasilkan memiliki nilai yang hampir sama dan sebagian lainnya cenderung acak, yakni pada sebagian data, nilai output lebih besar dari nilai target dan pada sebagian data lainnya nilai target lebih besar daripada nilai output.

3.4 Hasil Peramalan Debit Menggunakan ANN

Gambar harus diberi nomor, seperti contoh berikut.

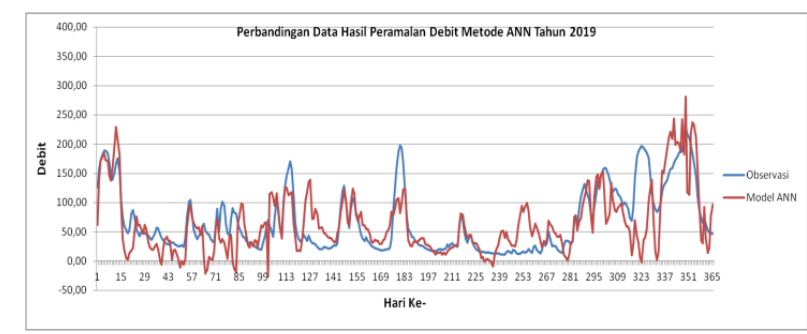

Gambar 6. Hasil Peramalan Debit Menggunakan Metode ANN

Dari Gambar 6 dapat dilihat bahwa debit hasil pemodelan menggunakan metode ANN cenderung mengikuti pola pada data debit hasil observasi walaupun ada sebagian data yang mengalami lonjakan nilai debit.

\subsection{Hasil Peramalan Debit Menggunakan SOM-ANN}

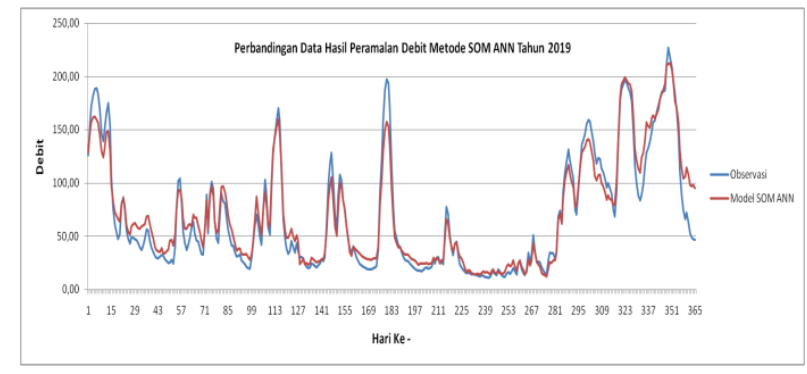

Gambar 7. Hasil Peramalan Debit Menggunakan Metode SOM-ANN
Berdasarkan Gambar 7 dapat dilihat bahwa debit hasil pemodelan menggunakan metode SOM-ANN memiliki pendekatan yang lebih baik dibandingkan hasil pemodelan dengan menggunakan metode ANN. Metode SOM - ANN mampu mereduksi kesalahan yang dihasilkan sehingga data debit hasil pemodelan dapat lebih mendekati data debit hasil observasi

\subsection{Perbandingan Performansi dan Akurasi}

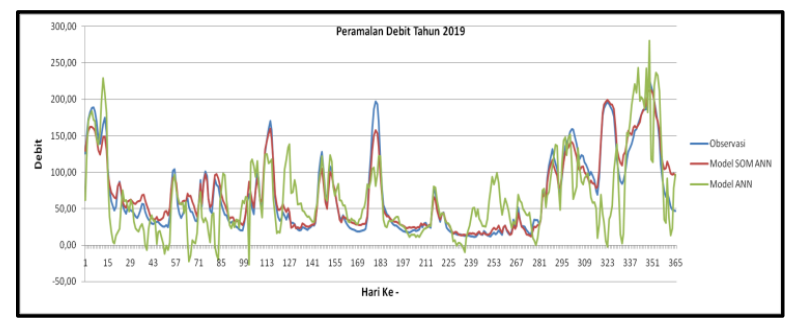

Gambar 8. Hasil Peramalan Debit Tahun 2019

Gambar 8 memperlihatkan grafik dari data debit hasil peramalan selama satu tahun yang dimulai dari data ke-1 atau tanggal 1 Januari 2019 hingga hari ke-365 atau tanggal 31 Desember 2019. Perbandingan hasil peramalan debit pada metode ANN dan metode SOMANN dapat dilihat dari perbedaan nilai debit hasil pemodelan yang dihasilkan, yakni pada metode SOMANN nilai debit yang dihasilkan memiliki pola yang lebih dominan mendekati nilai debit observasi dibandingkan dengan nilai debit pada metode ANN. Metode SOM-ANN dianggap mampu mengenali pola sehingga output yang dihasilkan bisa meminimalisir kesalahan peramalan terutama pada titik - titik puncak debit sehingga pendekatan yang dihasilkan lebih dapat dipercaya untuk dijadikan acuan pada Early Warning System yang akan dikembangkan jika dibandingkan dengan metode ANN.

\section{KESIMPULAN}

Berdasarkan hasil penelitian ini, dapat disimpulkan beberapa hal berikut:

1. Pada tahap pelatihan menggunakan metode ANN, menghasilkan nilai koefesien korelasi $\mathrm{R}=0,98051, \quad \mathrm{MSE}=0,00099999 \quad$ dan membutuhkan 7515 epoch, pada tahap pengujian menghasilkan nilai koefesien korelasi $\mathrm{R}=0,84606$ dan $\mathrm{MSE}=0,068444$, serta pada tahap validasi menghasilkan nilai $\mathrm{R}=0,89748$ dan MSE $=0,021141$. Pada tahap verifikasi, Model ANN menghasilkan tingkat kesalahan peramalan sebesar MSE $=1745,35$.

2. Pada tahap pelatihan menggunakan metode SOM ANN, menghasilkan nilai koefesien 
korelasi $\mathrm{R}=0,98653$, MSE $=0,00099947$ dan membutuhkan 5255 epoch, pada tahap pengujian menghasilkan nilai koefesien korelasi $\mathrm{R}=0,98733$ dan $\mathrm{MSE}=0,00099827$, serta pada tahap validasi menghasilkan nilai $\mathrm{R}=0,98867$ dan MSE $=0,00099819$. Pada tahap verifikasi, Model SOM ANN menghasilkan tingkat kesalahan peramalan sebesar MSE $=168,91$.

3. Metode SOM-ANN memiliki keunggulan dibanding metode ANN pada proses pembentukan jaringan dan pemodelan,hal tersebut dibuktikan dengan peningkatan Koefisien Korelasi (R) dan tingkat kesalahan (MSE) menurun pada tahap akhir pembentukan jaringan (validasi).

4. Pada penelitian ini, akurasi yang dihasilkan pada tahap verifikasi dengan Metode SOMANN memberikan peningkatan sebesar 9,67\% dan performa pada pelatihan jaringan berdasarkan jumlah iterasi / epoch yang dibutuhkan pada proses pelatihan meningkat secara signifikan sebesar $143 \%$ dibandingkan Metode ANN.

5. Model peramalan yang dibangun dengan Metode SOM-ANN mampu mereduksi kesalahan dalam peramalan dengan lebih baik dari pada Metode ANN sehingga lebih dapat dipercaya untuk dijadikan sebagai acuan pada Early Warning System.

\section{UCAPAN TERIMAKASIH}

Ucapan terimakasih kami sampaikan kepada pihak-pihak yang telah membantu dalam penelitian ini :

1. Kepada kedua orang tua penulis, Bapak Mustadir S.Pd dan Ibu Sunarti S.Pd

2. Bapak Dr. Imam Suparayogi, MT dan Bapak Dr. Ferry Fatnanta, MT selaku pembimbing penelitian. Serta Bapak Dr. Eng. Sigit Sutikno, MT, Bapak Dr. Muhamad Yusa, M.Sc, dan Ibu Dr. Lita Darmayanti, MT selaku dosen penguji

3. Balai Wilayah Sungai ( BWS ) Sumatera III Provinsi Riau yang telah memberikan data sekunder dalam penelitian ini

4. Seluruh Bapak dan Ibu dosen serta teman-teman mahasiwa Magister Teknik Sipil Angkatan 2017 ganjil, yang telah bersama-sama membantu dalam proses perkuliahan dan penelitian ini.

\section{DAFTAR PUSTAKA}

[1]Asdak, C. (1995). Hidrologi dan Pengolahan Daerah Aliran Sungai. Yogyakarta: Gadjah Mada University Press.

[2]Dewan SDA Nasional (2013). Pola Pengelolaan Sumber Daya Air Wilayah Sungai Siak Stranas 2013. Jakarta.

[3]Farias, C. A. S. (2015). Runoff-Erosion Modelling at Micro-Watershed Scale: a Comparison of Self-Organizing Maps Structures. Jurnal Geoenvironmental Disasters 2:14

[4]Fausett, L. (1994). Fundamentals of Neural Network; Architecture, Algorithms and Applications. Prentice Hall.

[5]Ghozali, Ariyaningsih, R. B. Sukmara, and B. U. Aulia, "A Comparative Study of Climate Change Mitigation and Adaptation on Flood Management between Ayutthaya City (Thailand) and Samarinda C'ity (Indonesia)," Procedia Soc. Behav. Sci., vol. 227, no. November 2015, pp. 424-429, 2016.

[6]Goel, A. (2011). ANN-Based Approach for Predicting Rating Curve of an Indian River. International Scholarly Research Network ISRN Civil Engineering, Volume 2011, Article ID 291370, 4 pages doi:10.5402/2011/291370.

[7]Harto, S. (1993). Analis is Hidrologi. Jakarta: Nafiri.

[8]Hermaw an, A. (2006). Jaringan Syaraf Tiruan Teori dan Aplikasinya. Yogyakarta: Andi Offset.

[9]Indarto. (2010). Hidrologi; Dasar Teori dan Contoh Aplikasi Model Hidrologi. Jakarta: Bumi Aksara.

[10]Isnanto, R. R. (2014). Penerapan Metode SelfOrganizing Map (SOM) untuk Visualisasi Data Geospasial pada Informasi Sebaran Data Pemilih Tetap (DPT). Jurnal Sistem Informasi Bisnis 01.

[11]Kristanto, A. (2004). Jaringan Syaraf Tiruan (Konsep Dasar, Algoritma dan Aplikasi). Yogyakarta: Gava Media.

[12]Kusumadewi, S. (2003). Artificial Intellegence (Teknik dan Aplikasinya). Yogyakarta: Graha Ilmu.

[13]Kusumadewi, S. (2004). Membangun Jaringan Syaraf Tiruan Menggunakan MATLAB dan EXCEL LINK. Yogyakarta: Graha Ilmu.

[14]Muis, B. Güneralp, B. Jongman, J. C. J. H. Aerts, and P. J. Ward, "Flood risk and adaptation strategies under climate change and urban expansion: A probabilistic analysis using global data," Sci. Total Environ., vol. 538, pp. 445457, 2015. 
[15]Tsauri, M, I, I (2017). Model Peramalan Debit Aliran Sungai Menggunakan Metode Gabungan Self Organizing Maps dan Artificial Neural Network. Tugas Akhir Jurusan Teknik Sipil.

Univesitas Riau. Pekanbaru 